\title{
Erratum to: Breastfeeding in Byzantine icon art
}

\author{
Ioannis D. Gkegkes • Vassiliki M. Darla •
}

Christos Iavazzo

Published online: 15 May 2014

(C) Springer-Verlag Berlin Heidelberg 2014

\section{Erratum to: Arch Gynecol Obstet (2012) 286:71-73}

DOI 10.1007/s00404-012-2252-3

Unfortunately, reference number 13 was published with incorrect detail in the original publication. The correct reference is given below.

Bartlett A (2005) Madonnas, models and maternity: icons of breastfeeding in the visual arts. http://www.usq.edu.au/ resources/bartlettpaper.pdf. Accessed 23 Oct 2011.

The online version of the original article can be found under doi:10.1007/s00404-012-2252-3.

I. D. Gkegkes

Department of Surgery, Korinthos General Hospital,

Corinth, Greece

V. M. Darla

Department of Sociology, School of Social Sciences,

University of the Aegean, Lesvos, Greece

C. Iavazzo $(\bowtie)$

IASO, Maternity Hospital, 38, Seizani Str.,

Nea Ionia, 14231 Athens, Greece

e-mail: christosiavazzo@hotmail.com 